\title{
TOLERANCE IN THE PIIL PESENGGIRI OF LAMPUNG SOCIETY
}

\author{
Mujiyati $^{1}$
}

\begin{abstract}
This study aims to produce a description within the meaning of tolerance in piil pesenggiri Lampung society. The scope of the study includes 1) an overview of tolerance of Lampung society; 2) Description of the meaning of tolerance in piil pesenggiri Lampung society; 3 ) the value of tolerance in guidance and counseling. This research uses a qualitative approach with the descriptive method. Participants were determined by purposive sampling, among other's traditional leaders (one person), community leaders (two people), and academics (three people) engaged in research in Lampung society. The research conducted, namely: 1) researchers construct the meaning of tolerance in pill pesenggiri passenger based on theory and research results; 2) the researcher clarifies to the participants (customary figures, community leaders, and academics) to constructions made through interviews; 3) the researcher performs data analysis by data reduction, and 4) the researcher conducts an interpretation of the constructs based on upon the results of the data analysis. Based on the results of data interpretation, the resulting definition of tolerance in piil pesenggiri is the recognition of the rights of others that are different from the cultural norms of Lampung culture applied in social life in the form of appreciating the difference, open and accept the opinions of others, caring, and give freedom to others in acting.
\end{abstract}

Keywords: Culture, Tolerance, Piil Pesenggiri, Lampung.

JOMSIGN: Journal of Multicultural Studies in Guidance and Counseling

Website: http://ejournal.upi.edu/index.php/JOMSIGN

Permalink: http://ejournal.upi.edu/index.php/JOMSIGN/article/view/6314

How to cite (APA): Mujiyati. (2018). Tolerance in the Piil Pesenggiri of Lampung Society. JOMSIGN: Journal of Multicultural Studies in Guidance and Counseling, 2(2), 82-91

This is an open-access article distributed under the terms of the Creative Commons Attribution 4.0 International License, which permits unrestricted use, distribution, and reproduction in any medium, provided the original work is properly cited.

\section{INTRODUCTION}

Since reform and democratization, Indonesia has faced a variety of new and very complex challenges. One of the most prominent is the cultural problem. In the cultural sphere, a shift in power from the center to the regions has a major impact on the recognition of local culture and its diversity. Culture as a nation's wealth, cannot be regulated by a centralized policy but must be developed in their respective local contexts (Liliweri, 2005). One culture that developed in Indonesia is Lampung culture.

${ }^{1}$ STKIP Muhammadiyah Pringsewu Lampung; muji2112@gmail.com 
Lampung culture is an opinion or understanding, outlook on life, design ideas that have been in the minds of the people. From a social and cultural perspective, Lampung is an area with unique socio-cultural characteristics (Hadikusuma, 1990). As an area, Lampung is well known by many people in Indonesia. And among Javanese people in the past, Lampung was one of the regions that promised a very good future. Many Javanese were sent by the colonial government during the Dutch colonial era, through a program known as "colonization", so that in Lampung this area was found with many Javanese colonies from the Dutch era, which later grew into centers of economic growth (Utomo, 1958; Depdikbud, 1976). The colonization program was then continued by the Indonesian government through the transmigration program, which reached more areas in Indonesia. Lampung or South Sumatra is still one of the transmigration destinations of interest to the Javanese, so the name Lampung is almost always associated with colonization and transmigration. Thus, the culture of Lampung originated not only from the native population but also from the culture brought by the migrants where acculturation took place dynamically. Therefore, local culture in Lampung society is the essence or essence of a culture that is abstract because it is based on views and experiences of human life that are different from each other. Although there is a culture of Lampung that is plural and dynamic, acculturation that occurs can synergize and be useful for regional development (Nurdin, 2009).

Awareness of the importance of pluralism began to emerge as the needs of individuals in the community developed, thus emphasizing the importance of tolerance in social life. Tolerance comes from the word "tolerate" which comes from Latin which means to patiently let something (Poerwadarminto, 1976). Tolerance can also be said in terms of socio-cultural and religious contexts which means attitudes and actions that prohibit discrimination against different groups or are not acceptable to the majority in society (Hasyim, 1979). Furthermore, Haricahyono (1995) explains the purpose of developing tolerance among students in schools and social groups, namely as a vehicle for training so that they can further implement and develop it widely in people's lives.

Tolerance is defined as a relationship between two systems that occur in such a way that events that occur in one system will affect events that apply to the other system. That is, tolerance is a social relationship between individuals so that they influence each other (Chaplin, 1985). The indicators of tolerance are social acceptance, ethnic appreciation, compromise, and cultural absorption (Chaplin, 1985). Therefore, the broad understanding of tolerance is an attitude 
or human behavior that does not deviate from the rules, where someone respects or respects every action taken by another person.

Lampung society is known as a society that is very tolerant of immigrant communities. This is following the principles of life philosophy adopted by the people in the context of living side by side with others, namely meeting nyimah, being open and accepting guests well (Fachruddin and Haryadi, 1996). This philosophy has been able to explain how the nature of the ethnic Lampung to other ethnicities, this is what causes the land of Lampung has extraordinary ethnic diversity and it is said that the Province of Lampung is one of the regions that become the State of the Republic of Indonesia where 80 percent of the population consists of ethnic migrants from various tribes in Indonesia (Shah, 1999).

The increasingly dynamic condition of Lampung society raises the question, do Lampung people remain calm and without a ripple in responding to the domination of migrants? The emergence of awareness to rise and represent themselves so that they are equal with migrants can be seen as Lampung people's resistance to the "onslaught" of a heterogeneous and dominant immigrant culture. Because it is increasingly marginalized, it is natural that Lampung people redefine their identity through the interpretation of the values contained in the piil pesenggiri as a representation of ethnic identity (Irianto \& Margaretha, 2013).

As a principle of piil life is usually interpreted as a sense of self-worth, never give up feeling easily offended, and feeling more than others. The word piil is usually combined with the word pesenggiri, life is usually interpreted as a sense of self-worth, never give up feeling easily offended, and feeling more than others. The word piil is usually combined with the word piil pesenggiri. Piil pesenggiri for Lampung people has the meaning as a way of life. That is, every move and step of the life of the people of Lampung in everyday life is based on the cleanliness of the soul (Hadikusuma, 1990). This action reflected vertical and horizontal relationships in Lampung society in the form of faith in God and social interaction with others. This ethos and spirit of the village must be developed to build the existence of Lampung people and markers of local wisdom in the current era of global diversity. In a broad sense, piil pesenggiri means "the rules of virtue in character, language, and behavior so that someone will be respected by others" (Martiara, 2012). In other words, the piil pesenggiri 
is the overall outlook on life, values, and norms of social life in the "native" Lampung community that is manifested in everyday life.

Over time, the philosophy of Lampung society's life contained in the piil pesenggiri experiences inaccuracy in its application even though some Lampung community groups still hold fast and even apply the contents of the piil pesenggiri well. Misinterpretation of the interpretation of piil pesenggiri also often occurs in the social activities of Lampung people. Especially young people who are also prone to misinterpretation of the piil pesenggiri points. The great piil pesenggiri made a sense of pride which could then hamper personal progress. Someone who misinterpreted the piil pesenggiri often felt that they did not need to study any better because they felt proud to ask for help or ask those who understood more about an area. Not to mention the openness of someone to accept criticism and constructive suggestions and awareness to continue to improve themselves because they are trapped by the wrong understanding of the piil pesenggiri. Piil pesenggiri which is misinterpreted will cause someone to become arrogant and lazy. There is a tendency to feel proud to study and work hard in areas that are considered inappropriate. Already a luxurious style so that it feels prestigious if it appears simple.

For the younger generation, piil pesenggiri considered a burden, especially if it is associated with marriage according to Lampung's customary procedures that are complete, expensive, and in the series of ceremonies as if showing the piil from each family. Piil pesenggiri s also often identified with violence (Hadikusuma, 1990). Various actions carried out by a group of young people, often legitimized in the name of piil pesenggiri, thus further aggravating the image of the Lampung tribe with its piil concept (Irianto \& Margaretha, 2013). Some actions always carry the piil as a "social weapon," to justify his actions.

From the facts about the piil pesenggiri above, it is clear that any attempt to understand the "native" Lampung community would not be able to succeed well without understanding piil as a basic view in their socio-cultural life. This is often the trigger of intolerance in adolescents at this time. Hadikusuma (1990) describes the causes of fighting problems in adolescents, namely: 1) weak emotional ties between groups that have cultural diversity; 2) culture that is believed by each group is often used as a justification tool in each act so that conflicts often occur; 3) unilateral mistakes or each group in understanding the knowledge and information received, giving rise to bad prejudice; and 4) the 
low desire, awareness, and willingness of each party to open themselves in resolving conflicts.

Based on the description above, it can be concluded that tolerance in this study means the nature or attitude of tolerance (respect, allow, allow) the establishment (opinions, views, beliefs, habits, behavior) that is different or contrary to his position. While piil pesenggiri means the overall outlook on life, values, and norms of courtesy in the people of Lampung, which are manifested in everyday life. The purpose of this study is to produce an objective description of meaning about tolerance in the piil pesenggiri community of Lampung.

\section{METHOD}

This research uses a qualitative approach with descriptive methods. Descriptive method is a method that studies the problems of society, the procedures that apply in society and certain situations, including about relationships, activities, attitudes, views or systems of thought, and processes that are ongoing and influence on phenomena (Nazir, 2003 ). The purpose of this descriptive method is to make a systematic, factual and accurate description, picture or painting of the facts, properties, and relationships between the phenomena investigated.

The determination of participants is done by purposive sampling. Purposive sampling is the determination of participants by determining specific characteristics that are following the objectives of the study so that it is expected to answer the research problem. This research will reveal the meaning of tolerance in the piil pesenggiri community of Lampung. Therefore, participants in this study were traditional leaders ( 1 person), community leaders ( 3 people), and academics (2 people) involved in research in Lampung society.

Data collection is done through the interview method. The purpose of this interview method is to obtain objective information from community leaders, traditional leaders, and academics related to the meaning of tolerance in the piil pesenggiri community of Lampung.

The stages of the research carried out are: 1) the researcher constructs the meaning of tolerance in the piil pesenggiri based on the theory and research results; 2) then, the researcher clarified the participants (traditional leaders, community leaders, and academics) to the construct made through interviews; 3) the researcher analyzes the data using data reduction as the process of selecting, focusing on simplifying, abstracting and transforming "rough" data 
that arise from written records in the field; and 4) the researcher interprets the construct based on the results of data analysis.

\section{RESULTS AND DISCUSSION}

The researcher constructs the meaning of tolerance in the piil pesenggiri based on the theory and research results that the piil pesenggiri is "recognition of the rights of others that are different from the norms of Lampung cultural customs that are applied in social life in the form of respecting and respecting differences, being open and accepting the opinions of others, care, grace, and give freedom to others in acting. "This definition researchers developed by conducting a comparative study between several theories and research results about the piil pesenggiri.

Furthermore, researchers conducted interviews with several experts (expert judgment) to refine the construct of the definition and give consideration to the implementation of tolerance in Lampung society. Some of these experts, consisting of one traditional figure namely Khaja Jukhagan as sebatin (Lampung King) on Coastal Lampung, two community leaders in the Pringsewu region and three academics who did a lot of research on Lampung culture.

Then the researcher analyzes the data using data reduction as the process of selecting, focusing on simplifying, abstracting and transforming "rough" data that emerges from written notes in the field. The results of data reduction from the interview are as follows in Table 1.

Table 1

The results of data reduction from the interview

\begin{tabular}{|c|l|l|}
\hline No & Judgment & \multicolumn{1}{c|}{ Results } \\
\hline 1 & Traditional & $\begin{array}{l}\text { 1. This definition meets the criteria in question. } \\
\text { 2. The definition can already represent the meaning of tolerance in } \\
\text { the pesenggiri piil, because tolerance in the pesenggiri piil gives } \\
\text { freedom to the community to express their respective opinions, } \\
\text { and recognizes the rights of others who are different from the } \\
\text { cultural norms of Lampung. } \\
\text { 3. In everyday life, the people of Lampung accept each other, } \\
\text { respect, care, and are always graceful in accepting differences. } \\
\text { 4. The value of tolerance in Lampung society has been carried out } \\
\text { because in everyday life mutual respect and respect for } \\
\text { differences in the opinions of others. } \\
\text { 5. The tolerance value can still develop in Lampung society because } \\
\text { Lampung people are still open and willing to accept the opinions } \\
\text { of others, care, and grace, giving freedom in action. }\end{array}$ \\
\hline
\end{tabular}




\begin{tabular}{|c|c|c|}
\hline No & Judgment & Results \\
\hline & & $\begin{array}{l}\text { 6. Efforts to instill tolerance in Lampung society in the form of } \\
\text { respecting and respecting differences in migrant communities. }\end{array}$ \\
\hline 2 & $\begin{array}{l}\text { Community } \\
\text { Leaders } 1\end{array}$ & $\begin{array}{l}\text { 1. This definition is fulfilled because it has drawn benchmarks to be } \\
\text { used. } \\
\text { 2. The definition formulated in the meaning of tolerance can already } \\
\text { represent the philosophy of piil pesenggiri because the four } \\
\text { supporting elements, such as 1) respecting guests or migrants, 2) } \\
\text { being social, 3) like giving and receiving; and 4) please help } \\
\text { already included. } \\
\text { 3. From the aspect of tolerance, the definition formulated already } \\
\text { illustrates the value of tolerance in Lampung people's lives. This } \\
\text { is proven by the fact that any culture can develop in Lampung as } \\
\text { long as it is still in line with prevailing cultural customs. } \\
\text { 4. Until now tolerance is still maintained according to the corridor } \\
\text { because the values of the piil pesenggiri as a guideline for } \\
\text { Lampung society are in line with the philosophy of Pancasila and } \\
\text { Islam. } \\
\text { The inculcation of tolerance values in Lampung society is carried } \\
\text { out by traditional leaders in each customary activity and } \\
\text { government service efforts in all aspects of life in line with the } \\
\text { values of piil pesenggiri. }\end{array}$ \\
\hline 3 & $\begin{array}{l}\text { Community } \\
\text { Leaders } 2\end{array}$ & $\begin{array}{l}\text { 1. With tolerance to piil pessenggiri it can give rights to differences. } \\
\text { 2. The definition can already represent because tolerance to the } \\
\text { pesenggiri is important as a moral order to provide guidelines for } \\
\text { personal behavior and indigenous peoples of Lampung. } \\
\text { 3. The definition already illustrates the value of tolerance in } \\
\text { Lampung society because tolerance in the piil pesenggiri is a } \\
\text { tolerance of the socio-cultural potential of the region which has } \\
\text { meaning as a source of motivation so that everyone is dynamic to } \\
\text { fight for positive values, respectful life and respect in life the } \\
\text { community. } \\
\text { 4. The value of tolerance is still developing because in a society of } \\
\text { tolerance it is still held fast to reach an agreement together with } \\
\text { the Lampung community. }\end{array}$ \\
\hline 4 & $\begin{array}{l}\text { Academics } \\
1\end{array}$ & $\begin{array}{l}\text { 1. I agree with this definition because the form of piil pesenggiri } \\
\text { which is instilled from generation to generation is a form of being } \\
\text { carried out to be ready to face people outside the Lampung tribe } \\
\text { who have long and increasingly grown alive in Lampung. } \\
\text { Besides, Piil Pesenggiri which is often taught by elders } \\
\text { (grandparents, grandparents and parents) is always closely } \\
\text { related to Sai Bumi Khua Jukhai, which was interpreted at first as } \\
\text { the land of Lampung which has two dialects in the Lampung } \\
\text { tribe, namely dialects A and O. However, as time goes by, } \\
\text { Lampung is not only supported by the Lampung tribe. Many } \\
\text { migrants who have lived or settled and produce offspring in the } \\
\text { land of Lampung, so that the piil pesenggiri which was originally } \\
\text { a safeguard of self-esteem among the Lampung dialects A and O } \\
\text { only, has shifted to guarding self-esteem in multicultural societies } \\
\text { to remain able to coexist with other tribes, but still maintain self- }\end{array}$ \\
\hline
\end{tabular}




\begin{tabular}{|c|c|c|}
\hline No & Judgment & Results \\
\hline & & $\begin{array}{l}\text { esteem by continuing to inherit Lampung's customs and culture } \\
\text { for generations. } \\
\text { 2. The definition can already represent the meaning of tolerance and } \\
\text { piil pesenggiri. } \\
\text { 3. The definition has descriptively described the value of tolerance } \\
\text { but has not been applied to everyday life as a whole. } \\
\text { 4. Efforts to instill tolerance values in Lampung society in the form } \\
\text { of tolerance in adat are the appointment of relatives other than the } \\
\text { Lampung tribe known as Angkon which means recognition. }\end{array}$ \\
\hline 5 & $\begin{array}{l}\text { Academics } \\
2\end{array}$ & $\begin{array}{l}\text { 1. The definition can already represent the meaning of tolerance } \\
\text { because in the definition it combines the intent of the relationship } \\
\text { of behavior or attitudes that represent themselves in society. } \\
\text { 2. It is necessary to add examples of Lampung people's } \\
\text { habits/actions that represent the pesenggiri piil (for example a } \\
\text { special term in Lampung language) so that the definition can } \\
\text { represent the indigenous people of Lampung. } \\
\text { 3. This definition already illustrates the value of tolerance, } \\
\text { although, in reality, it is necessary to reemphasize the values and } \\
\text { norms of the Lampung tradition in the community, so that the } \\
\text { community can understand the indigenous tribes of Lampung, } \\
\text { considering that Lampung is a province whose society is } \\
\text { heterogeneous. } \\
\text { 4he tolerance value is still developing in Lampung society today, } \\
\text { for example in one of the regencies in Lampung province, namely } \\
\text { Pringsewu Regency, there is a village inhabited by indigenous } \\
\text { tribes of Lampung, the village area is surrounded by Javanese } \\
\text { people, will but the system of civilization, the values of tolerance } \\
\text { in the piil pesenggiri are still maintained. } \\
\text { 5. Efforts to instill tolerance values in Lampung society are to } \\
\text { participate in activities such as attending traditional Lampung } \\
\text { wedding events, selection of muli mekhanai, title selection, grand } \\
\text { cangget. }\end{array}$ \\
\hline 6 & $\begin{array}{l}\text { Academics } \\
3\end{array}$ & $\begin{array}{l}\text { 1. The definition is quite clear but still too universal. } \\
\text { 2. The definition cannot yet represent the meaning of tolerance in } \\
\text { the piil pesenggiri because the meaning of the piil pesenggiri has } \\
\text { not yet been fully defined. } \\
\text { 3. For the piil pesenggiri it is necessary to add matters relating to } \\
\text { the principle of self-esteem because the definition is more } \\
\text { inclined to the philosophy of being mixed up (mingling, } \\
\text { socializing) } \\
\text { 4. The definition does not fully describe the tolerance value in } \\
\text { Lampung society because Lampung people are open to migrants } \\
\text { (as evidenced by a large number of transmigration areas). } \\
\text { However, it is undeniable that many social problems are triggered } \\
\text { by a lack of tolerance. } \\
\text { 5. The tolerance value is still developing, especially in a society that } \\
\text { has lived side by side with a heterogeneous ethnic composition. } \\
\text { 6. Efforts to instill tolerance values in Lampung society take the } \\
\text { form of socialization or condition the differences in an organized }\end{array}$ \\
\hline
\end{tabular}




\begin{tabular}{|l|l|l|l|}
\hline No & Judgment & \multicolumn{3}{|c|}{ Results } \\
\hline & & $\begin{array}{l}\text { forum (for example exchange of students from various } \\
\text { backgrounds). }\end{array}$ \\
\hline
\end{tabular}

Based on the results of data reduction, a description of the meaning of tolerance obtained in Lampung people's piil pesenggiri is "recognition of the rights of others that are different from the cultural norms of Lampung that are applied in social life in the form of respecting and respecting differences, being open and accepting the opinions of others, care, grace, and give freedom to others in acting ". This definition will continue to evolve with changing times and following the value of openness held by the people of Lampung, and the values of tolerance can continue to be developed in various traditional Lampung activities as cultural heritage for future generations.

\section{CONCLUSION}

Based on the results of the study, an understanding is obtained that the definition of tolerance in the piil pesenggiri can already represent the meaning of tolerance in Lampung society. Therefore, the definition of tolerance in the piil pesenggiri is recognition of the rights of others that are different from the norms of Lampung cultural customs that are applied in social life in the form of respecting and respecting differences, being open and accepting the opinions of others, caring, graceful, and gives freedom to others in acting.

\section{REFERENCES}

Chaplin, J. P. (1985). Dictionary of psychology. Published Random House Publishing.

Depdikbud. (1976). Monografi daerah Lampung. Jakarta: Proyek Pengembangan Media Kebudayaan, Ditjen Kebudayaan Departemen Pendidikan dan Kebudayaan.

Fachruddin, \& Haryadi. (1996). Falsafah piil pesenggiri sebagai norma tatakrama kehidupan sosial masyarakat Lampung. Bandar Lampung: Arian Jaya.

Hadikusuma, H. (1990). Masyarakat dan adat budaya Lampung. Bandung: Mandar Maju. 
Haricahyono, C. (1995). Dimensi-dimensi pendidikan moral. Semarang: IKIP Semarang Press.

Hasyim, U. (1979). Toleransi dan kemerdekaan beragama dalam Islam sebagai dasar menuju dialog dan kerukunan antar agama. Surabaya: Bina Ilmu.

Irianto, S., \& Margaretha, R. (2013). Piil pesenggiri: Modal budaya dan strategi identitas ulun Lampung. Hubs-Asia, 9(1), 140-150.

Liliweri, A. (2005). Prasangka \& konflik: Komunikasi lintas budaya masyarakat multikultur. Yogyakarta: LKiS Pelangi Aksara.

Martiara, R. (2012). Nilai dan norma budaya lampung: dalam sudut pandang strukturalisme (Vol. 1, No. 1). Yogyakarta: Program Pascasarjana Institut Seni Indonesia Yogyakarta.

Nazir, M. (2003). Metode penelitian. Jakarta: Ghalia Indonesia.

Nurdin, A. F. (2009). Integralisme Islam dan nilai-nilai filosofis budaya lokal pada pembangunan propinsi Lampung. UNISIA, 32(71), 81-97.

Poerwadarminto, W. J. S. (1976). Kamus besar bahasa Indonesia. Jakarta: Balai Pustaka.

Syah, I. (1999). Sejarah kebudayaan Lampung. Lampung: Universitas Lampung.

Utomo, K. (1958). Masyarakat Transmigran Spontan di Daerah Way Sekampung (Lampung). Majalah Teknik Pertanian, Tahun ke VII, Nomor 7, 8, dan 9, Juli-September, p. 170185. 